\title{
The roots of gender bias: misogynist hadiths in pesantrens
}

\author{
Marhumah \\ Faculty of Education, State Islami University Sunan Kalijaga, Yogyakarta \\ E-mail:emar_62@yahoo.com
}

DOI: $10.18326 /$ ijims.v5i2.283-304

\begin{abstract}
Women are regarded as "the second class" by some people in pesantrens. This knowledge has rooted in hadiths cited in the books studied and implemented in many pesantrens. To counteract this tendency, it is therefore important to use a feminist approach to review and criticize the books which can also be used to understand and solve the problems of mis-interpretation of religious texts. The misogynist hadiths have been widely circulated and taught in pesantren under the authority of Kyai (male religious clerics) and nyai (female religious cleric) who have the authority to decide which hadiths are allowed to be taught and socialized in religious teachings and sermons. This is because many teachers emphasize the importance of preserving tradition and religious norms disegarding gender bias. Some feminist activists have tried to reform the mindsets of pesantren leaders both male and female by changing the authoritarian model of leadership to a democractic one. To do this, new historical, sociological and anthropological approaches are required to re-interpret and contextualize misogynist hadiths.
\end{abstract}

Perempuan dianggap sebagai warga "kelas dua" dalam beberapa kitab yang diajarkan di pesantren. Pengetahuan ini memiliki akar yang kuat dalam hadithhadith yang dikutip dalam buku-buku yang diajarkan di pesantren. Untuk 
melawan arus kecenderungan ini, penting untuk menggunakan pendekatan feminis dengan meninjau kembali dan mengkritik kitab-kitab tersebut. Pendekatan ini dapat digunakan sebagai cara untuk memahami dan menyelesaikan masalah kesalahan tafsir pada teks teks keagamaan. Hadith-hadits misoginis (membenci perempuan) diajarkan secara luas di pesantren di bawah wewenang Pak Kyai atau Ibu Nyai yang menentukan kitab-kitab mana yang boleh dan dilarang di pesantren. Para guru tersebut lebih mementingkan menjaga tradisi dan norma-norma agama yang seringkali bias jender. Beberapa aktivis feminis telah mencoba mereformasi pola pikir para pengasuh pesantren baik laki maupun perempuan dari kepemimpinan yang otoriter ke kepemimpinan yang demokratis. Untuk itu, pendekatan-pendekatan historis, sosiologis dan antropologis yang baru diperlukan guna memahami ulang hadith-hadith misoginis tersebut.

Keywords: Pesantren;Mysoginist; Hadith; Feminism

\section{Introduction}

Hadiths as words, deeds and decrees of the Prophet Muhammad are the second foundation of Islamic teachings after the Quran. It continues as living values for many Muslims. However, ulama have differed concerning hadiths as a continuous tradition for muslims. ${ }^{1}$ The shift in views about the tradition of the prophet Muhammad leads to the existence of position, function and relevance of the prophet: his position as prophet, statesman, judge and husband. It is important to contextualize the hadiths according to the different conditions in which they were narrated.

On the substantial understanding of the hadiths, according to Fazlur Rahman, the sunnah as a normative tradition should be viewed as, first, an exemplary concept with guidelines that contain special provisions. Therefore, it is necessary to understand that the tradition of the prophet

\footnotetext{
${ }^{1}$ Subhị Șălih, 'Ulūm al-Ḥadìth wa Muștalah, Beirut: Dār al-'ilm li al-Malāyin, 1988, 3-5; Muhammad 'Ajjāj al-Khātib, Ușul al-Ḥadïth wa Muṣtalah, Beirut: Dār al-Fikr, 1989, 17-28.
} 
has both contextual and historical-sociological frameworks.

As a model to guide people in their daily lives, the content of the hadith is not absolute. Secondly, the sunnah, literally, can also be applied to all the behaviors of the prophet. All behaviors are expressed as a pattern to imitate the prophet. The sunnah was actually derived from the practice of the muslim community. The sunnah is normatively the interpretation of the prophet, which later metamorphosed into "living sunnah" and actual Sunnah. ${ }^{2}$

\section{Power and epistemology in misogynist hadiths}

Historically, power and knowledge are closely related. The concept of science and truth are biased towards males because they are the dominant producers of knowledge in a male dominated society. In this regard, the process of socialization of hadiths in pesantren implies a relationship of power through various means ${ }^{3}$ such as disciplinary coersion and systemic behavior based on certain values, ${ }^{4}$ recognition and acceptance of authority, values, rituals, symbols and cultural supremacy of certain truths, ${ }^{5}$ control of culture, and ${ }^{6}$ institutionalization of norms through symbols, figures and role models. Moreover, the socialization of misogynist hadiths

${ }^{2}$ Fazlurrahman, Membuka Pintu Ijtihad, trans. Anas Mahyudin, New York: Library, 1984, 38-131; see also Taufiq Adnan Amal, Islam dan Tantangan Modernitas, Bandung: Mizan, 1990, 165-168.

${ }^{3}$ D. A. Rosenthal and Feldman, S. S., "The Acculturation of Chinese Immigrants: Effects on Family Functioning of Length of Residence in Two Cultural Contexts", Journal of Genetic Psychology, Vol. 4, (1990), 495-514.

${ }^{4}$ Aziz Talbani dan Parven Hasanali, "Adolescent Females Between Tradition And Modernity: Gender Role Socialization In South Asian Immigrant Culture", Journal of Adolescence, Vol. 23, (2000), 616.

${ }^{5}$ Aziz Talbani dan Parven Hasanali, "Adolescent Females Between Tradition and Modernity”..., 616.

${ }^{6}$ J.S. Hirst and Thomas L. "Introduction: Playing for Real: Hindu Role Models, Religion and Gender," in J.S. Hirst, and Thomas L. (ed.), Playing for Real: Hindu Role Models, Religion and Gender, Oxford: Oxford University Press, 2004, 2-3. 
is generally regarded as a strategy to reinforce and maintain male power in the community. ${ }^{\text {? }}$

From a feminist perspective, the meaning of the "historical effect" of truth is understood as a negative consequence of the production of discourses which act to stipulate, confine and regulate how women negotiate gender.

\section{Naqd al-sanad and naqd al-matan: bridging misogynist hadiths}

The study of hadiths has developed significantly over time, both from the aspect of sanad and matan as well as new ideas and discourses. Various methods and approaches have been offered by scholars of the hadiths to explore the meaning of the hadiths.

The history of the hadith criticism has been started by Imam Muslim since the 3rd century of the Islamic calendar. His critics were written in his book entitled al-Jarh wa al-Ta'dil which explored the authenticity of the hadiths based on works done by the Prophet's Companion, Abu Bakr as-Siddiq. Both are the pioneers of hadith criticism. ${ }^{8}$ In al-Jarh wa al-Ta'dil, the narrators of the hadiths should be scrutinized based on their personal qualities and intellectual capacities. ${ }^{9}$

Similarly, naqd al-matan or matan criticisms should be done to find out the true or original traditions, and, at the same time, to disregard the false ones. This is conducted by critically examining and analyzing the historical facts of the hadiths to determine whether they can be proven as valid or made up. ${ }^{10}$ The critical tradition has been valued highly since

${ }^{7}$ Aziz Talbani dan Parven Hasanali, "Adolescent Females Between Tradition and Modernity..., 616.

${ }^{8}$ Nawir Yuslim, 'Ulum al-Hadith, New York: Pearl Source Widya, 2001, 330-334.

${ }^{9}$ See al-A'zami, M. Mustafa, Manhaj al-Naqd 'inda al-Muhaddithin, Riyadh: al-'Umayroh, 1982, 5.

${ }^{10}$ Muhammad Tahir al-Jawaby, Juhūd al-Muhaddithin Naqd fi al-Matn al-Hadīth al-Sharif al-Nabawy, Tunis: al-Karim ibn 'Abdillāh, 1986, 94. 
the era of the Prophet. The companions of the Prophet had tried to confirm, clarify and test the accuracy of a hadiths. This tradition had continued for a long time in order to protect the true hadiths from the false ones, as delivered by Abu 'Umar bin Khattab to Musa al-'Asy'ari. ${ }^{11}$ Similar critical traditions had also been carried out by the next generation of Tabi'in. ${ }^{12}$

This critical method of naqd matan can be applied to examining misogynist hadiths which have been intensely studied in recent years. There are several ways to analyse the misogynic hadiths. The best way is to standardize the substance of the verses of the Quran, for example on such issues as justice and equality. Firstly, principles of justice must be applied to determine the equal rights and obligations of men and women. Therefore, injustice is against God's will. Secondly, the principle of equality is extensively recorded in the Quran, such as in al-Ahzäb, verses 35-36. ${ }^{13}$ In understanding the Islamic perspective on issues of women and gender equality, it is important to focus on universal messages of humanism in Islam. ${ }^{14}$ Islamic ethics also support equality. ${ }^{15}$ The principles in the Quran ${ }^{16}$ and hadiths ${ }^{17}$

${ }^{11}$ Musfir 'Azmillah al-Damami, Maqāyis Naqd Mutūn al-Sunnah, Riyad: Saudiyah al, 1984, 61-106.

${ }^{12}$ See al-Khatib al-Bagdadi, al-Kifāyah fi 'Ilm al-Riwāyah, Beirut: Dār al-'Ilmiyyah, 1358 $\mathrm{H}, .287$.

${ }^{13}$ Indeed, it is believed that for male and female Muslims who remain obedient, true to male and female humility, who give charity, who fast, maintain their honour, and call , name of Allah, Allah has prepared for them forgiveness and a great reward.

${ }^{14}$ In this case for instance, Abdullah Ahmed An-Na'im, Dekontruksi Syariah, Yogyakarta: LKiS, 1994, 338.

${ }^{15}$ For example, Nazaruddin Umar, Argumen Kesetaraan Gender Perspektif Al-Qur'an, New York: Paramadina, 1999.

${ }^{16}$ For example, Masdar F. Mas'udi, Islam dan Hak-Hak Reproduksi Perempuan, Bandung: Mizan, 1997.

${ }^{17}$ For example, Khaled Abou El Fadl-, "Faith-Based Determination Assumptions and demeaning to Women”, in R. Hidayat, S. Schlossberg, and AH Rambadeta (eds), Islam, Women and the New World Order, New York: Center for Women's Studies UIN Sunan Kalijaga, 2006, 2-16. 
encourage humanism and progressive Islam. ${ }^{18}$ The Quranic verses on the origin of humans, religious ethics, and Islamic family law also encourage equality between men and women. ${ }^{19}$ Similarly, the teachings of Islam contain principles of justice in line with the universal declaration of human rights. ${ }^{20}$

Principles of equality between the sexes are embedded in the teachings of Islam. Inequality between men and women in many religions is socially and culturally constructed. They are not created by religion. In fact, all muslims are equal before Allah. The only differences among them are the quality of their piety which only Allah knows as piety is closely related to the heart. Thirdly, deliberation or democracy. This means that the aspirations of men and women are equally important.

\section{Misogynist hadiths according to the perspective of maqāșid al- Sharīa}

The term maqaṣid has often been discussed in the context of the development of Islamic law. It is popular among scholars of both classical and contemporary uṣul fiqh from al-Juwainy $(478 \mathrm{H})$, and currently utilized by the modern scholar, Jasser Auda ${ }^{21}$ who wrote an interesting book entitled alMaqāsid for beginners. The book highlights some important points: First, the basic maqașid are protecting 5 basic principles of Islamic law, i.e, protecting five elements of darūriyyat al-maqāạid (basic needs), namely protect-

\footnotetext{
${ }^{18}$ For example, Asghar Ali Engineer, The Rights of Women in Islam, New York: St.Martin's Press, 1996, 12.

${ }^{19}$ Umar, Argumen Kesetaraan Gender Perspektif Al-Qur'an..., 67.

${ }^{20}$ An-Na'im, Dekontruksi Syariah..., 338.

${ }^{21}$ Jasser Auda is the director and founder Maqasid Research Center in Philosophy of Islamic Law in London, England, and was a guest lecturer for the Faculty of Law, University of Alexandria, Egypt, the Islamic Institute of Toronto, Canada and the Islamic Fiqh Academy, India. He became a lecturer in Islamic law, philosophy, and material related to issues of Muslim minorities and policy in several countries around the world. Jasser Auda, Al Maqasid untuk Pemula. Trans. Ali Abdelmon’im , Yogyakarta, Diva Press, 2013, 139 -142,
} 
ing the right to life, to have livelihood, to be able to reproduce, to embrace one's own religion freely, and to have honour, respect and dignity. ${ }^{22}$ There are some indicators that can be used to establish maqașid al-shari' $a$ in the contemporary era.

The main consideration is of maqașid al-shari' $a$ as basic human rights. ${ }^{23}$ Another thing that is offered by Jasser Auda is how maqașid al-shari' $a$ can be utlized in many aspects of modern problems. ${ }^{24}$ It is also important that Jasser Auda has provided a very positive contribution in applying maqāsid alshari'a to the examination of the texts of the Quran and the hadiths. In principle, the Quran and hadith should be integrated. Thematic interpretation can open up opportunities for moral principles to be the foundation for all the rules of Islamic law. For this reason, the hadiths should be viewed in context. ${ }^{25}$ Related to the issues on women, it is important to regard the hadiths not merely in terms of normativity, but also on the substance of the teachings of these traditions. Jasser Auda's approaches to maqașid thus are very important on both philosophical and substantial levels. Therefore, they should be reconciled and integrated to other traditions in examinations of the hadiths. Maqāsid can be the core of all ijtihàd, both the fundamental and rational.

\section{Indoctrination of misogynist hadiths in pesantrens}

Islamic boarding schools (pesantren) have a very strong tradition in disseminating values and transforming the thinking of students. Similarly, studies and texts used in boarding school are generally ideological and dogmatic. The method of transmission of the knowledge of the Kyai and Nyai is often in the form of a monologue, mainly based on their religious

\footnotetext{
22 Jasser Auda, Al Maqasid untuk Pemula..., 50.

${ }^{23}$ Jasser Auda, Al Maqasid untuk Pemula..., 59.

24 Jasser Auda, Al Maqasid untuk Pemula..., 82.

25 Jasser Auda, Al Maqasid untuk Pemula ..., 85-86.
} 
authority. ${ }^{26}$ Since their inception, these boarding schools have been a center of learning and preaching. They have played important roles as the oldest system of learning and education in Indonesia. Before modern education was introduced by the Dutch, the pesantren was the only education system in Indonesia. ${ }^{27}$ Further, Islamic boarding schools have played an important role in the spread of Islam in Indonesia. They have become the medium of formal socialization on Islamic beliefs, norms and values, transmitted and implanted through teaching. Thus, the function of the Islamic boarding school has been as guardian and propagator of Islamic orthodoxy. ${ }^{28}$

This orthodoxy hinders tolerance towards new developments and ideas in pesantren, which have been suspected of intolerance towards religious difference and for generating a new breed of ultra-conservative Islamic jihadist terrorists. Suspicion from outside can lead to religious fundamentalism. This model seems to be the mainstream in the pesantren of Nadathul Ulama (NU). This trend continues by rejecting such ideas as pluralism, human rights, and the environment.

Changes have occurred, however, in the pesantren milieu. For example, in the 1950s pesantren were established that catered for women. Despite this, the process of teaching and the content of the curriculum of the pesantren are still loaded with gender bias. There are many misogynist hadiths circulated and taught in the pesantren. The position of women is taught as subordinate to that of men, as Islamic values and cultures are more paternalistic. Culturally and normatively, the gender bias inherent within pesantren has led to discrimination against women in the pesantren context and beyond. More often than not in pesantren,

${ }^{26}$ Abdurrahman Wahid, "Introduction to the book", Kitab Kuning, Pesantren dan Tarikat, Bandung: Mizan, 1995, 11-12.

27 Zamakhsyari Dlofier, Tradisi Pesantren, Jakarta: LP3ES, 1982, 18.

${ }^{28}$ Endang Turmudi, Perselingkuhan Kyai dan Kekuasaan, Yogyakarta: LKIS, 2004, 37. 
students are exposed to misogynist hadiths which are not explained or contextualised in relation to the present. Based on a series of visits to pesantren I found ample evidence of the teaching and application of misogynist hadiths in the pesantren mileiu. First, based on my observations, many Kyai and their assistants maintain patriarchal domination. Normative teachings that exist in the misogynist traditions put emphasis more on traditional gender roles such as maintaining the traditional division of labor, i.e., women in the domestic sphere and men in the public sphere. This has become the main orientation in the Islamic boarding school environment and represents the official gender discourse in pesantren. Many Kyais and their senior assistants are still "traditionalist" and tend to be textual or literalist in regard to the roles of the women. They also tend to close themselves off from new and progressive ideas about gender in Islam.

The pesantren teacherHs perpetuate the hegemony of patriarchal traditions by maintaining existing practices and by using the gender-biased textbooks. The influence of misogynist hadiths in the textbooks is strengthened by the teachers' interpretations and understandings of the gender bias in the texts. For example, when the kyai reads and explains the book entitled, Qurrat al' 'Uyun, about the relationship between men and women in the family, they remind the young women to stick to their traditional roles as mothers by getting married in the near future.

\section{Methods of disseminating misogynist hadiths in pesantren}

The main teaching methods used in pesantren are authoritarian (topdown) and monolog (one-way). These are called strong models. According to Brittan and Maynard, this model assumes that the misogynist gender-specific discourses are established and widely accepted. The discourses are constantly disseminated to shape behavior, actions and gender iden- 
tity based on certain preferences that have been received. Gender identity is mainly formed through a longterm process of socialisation in which repetition is vital. ${ }^{29}$ Individuals are treated as passive subjects that can be shaped through indoctrination by the main agents of socialization which are gender biased.

The processes of indoctrination of misogynist hadiths in boarding school is enacted through the social structure established whithin the pesantren. This structure helps to create and shape the gender identities of the students who are regarded as passive recipients of misogynist hadiths and cultures. New pedagogical approaches become one of the main ways in spreading the hadiths. In the boarding schools, students not only learn in formal classes but also outside class, from their teacher, especially the Kyai, the Kyai's assistants, as well as from their peers. Role models play a crucial role in shaping the mindset, behavior and character of students. Teachers in educational institutions such as boarding schools serve as transmitters and role models for the unquestioned indoctrination of misogynist hadiths.

Teaching materials are essential in indoctrinating misogynist hadiths, particularly, through different themes and texts. This is because many Kyais, teachers, housekeepers and their assistants have similar views on traditional gender concepts in normative Islam, in which women are marginalized.

The above practice is closely related to other factors that also characterize the model of socialization of misogyny at the school, namely the prestige and authority of science, the Kyai, the housekeepers, as well as teachers. As mentioned previously, authority is an important factor in the transformation of culture and science education in the boarding school.

${ }^{29}$ Arthur Brittan dan Mary Maynard, Sexism, Racism, and Oppression, New York: Basil Blackwell, 1984, 71. 
The ability to deliver traditional teachings and assert their control of the doctrines acts as a guide for the students and sanctions their moral and intellectual capacities. Because of this, the scientific authorities in boarding schools, especially the Kyai, are always regarded as models and references for students.

Other practices strengthening ascribed gender roles include coercion and threats to students. They are warned to follow 'orthodox' doctrines and understandings that are often gender biased, otherwise, they are regarded as against Islam. During the learning process, threats are often posed so that students quickly learn to safeguard themselves because this kind of teaching creates a sense of worry: they attempt to avoid being accused as an enemy of Islam. Students are fear the threats and forced to apply the teachings in their lives. This practice has become important factors in the formation of gender sensitivity in pesantren. Pesantren regulations are also effective in controlling the discipline and behavior of students by punishment.

\section{Misogynist hadiths in Kitab Kuning}

The books containing misogynist hadiths taught in pesantrens are written by Syaikh al-Bajūry (d.1277/1861) and others. The authors were mostly male. The topic and structure of the books did not regard the equality between men and women. In these texts, it was common that women were regarded as the objects of the sexual needs of men. In the following section I outline the most significant aspects of the texts used in pesantren education in Indonesia.

\section{Kitāb al-Adhkār}

Kitāb al-Adhkār book was written by al-Nawawy ad-Dimasyqi. It was later republished by Thoha Putra publishing house in Semarang Central Java and contains misogynist hadiths. In the chapter entitled al-nikăh (the 
marriage), the author discusses Prophet Muhammad as a man who proposes a woman. The text explains that it should be the man who should propose a woman because of Allah. The man should also love a woman because of Allah.

Other topics in the chapter are about "marriage," which explain the conditions, approval and agreement which should be recited in the wedding ceremony. Other important topics discussed include the way husband and wife have sex and the way husbands treat their wives during sex. It is clear that the author does care about women and he suggests that men should take care of their wives when having sex. When a teacher ${ }^{30}$ explained marriage according to this book, all of the students look so enthusiastic and interested, yet the explanation from the teacher was that a man should be given sexual satisfaction.

\section{Kitāb Akhlāq al-Nisā'}

This book was written by Muslih bin Miftah and printed by Maktabah Munawwir, in Semarang, Central Java (no year of publication). The book starts by describing al-Fatihah, sholawat and peace upon the Prophet Muhammad. According to the title of the book, this book discusses the relationship between husband and wife and is only taught to female students because its contents are especially for women. The first chapter begins with a topic on the kindness of women. A hadith from Abdillah ibn 'Amr ibn 'Ash; al-dunyā matā' wa khair mata 'ih $\bar{a}$ al-màr'ah al-șalihah", is interpreted as, this world is full of grace, and the most graceful thing is a good woman. The explanation of a good woman in this text is based on an example of a friend of the author whose wife rebeled against her husband. She is thus regarded as disobedient and greedy. The stories

30 The book is read every Sunday and Monday evening between maghrib and Isha prayer times. 
state further that although they had three children, his wife had never served him. When the husband came home from work, his wife never took care of him or served him a cup of coffee. The husband had to prepare his meals and beverages by himself and does not know that his wife is having an affair. In the end, his wife runs away from her husband with her boyfriend. The explanation about the hadith is to emphasize that the woman should perform important role to maintain household. The story portrays the disobedient wife.

The second chapter discusses a hadith narrated by Abu Hurairah, i.e., "khair al-nisā' imra'atun in hadarta ilaiha sarratka wa in amartaha atä'atka, wa in ghibat 'anhā hafizatka fi mālika wa nafsiha" which means that a good woman is one who is able to make her husband happy when he is looking at her, obey him when being commanded, and protect herself and her husband's property when she is left alone at home. The author then explains the hadith that states "if the husband comes home from work she must make sure that all the domestic jobs have been done. The fragrance of the bed must be good. She must welcome her husband by kissing his hand. She must not eat before her husband has eaten." The author further suggests that the wife should educate their children, especially the girls and teach them to kiss their parents' hands.

In the third chapter, the author explains a hadith from Anas ibn Malik, i.e., al-mar'ah idhā șallat khamsahā wa șummat shahrahā wa hafizat farjahā wa ațā'at zaujahà tadkhulu min ayyi bäbin shä'at min abwäb al-jannah". It means that if a woman performs five times praying a day, fasts perfectly, managing herself, and obeying her husband, she will be rewarded to enter paradise in hereafter.

In the next chapter, chapter IV, there is a hadith narrated by Abd Rah\}mān bin 'Auf, said that The Prophet said: "al-mar'ah al-șälihah khair min alfi rajulin gair șălih. Wa ayyuma imra'at khadamat zaujahā sab'at ayyām 
ugliqa 'anhā sab'at abwāb al-nār wa futihat lahā thamāniyyat abwābi jannātin tadkhulu min ayyihā shä'at bi gairi hisāb." This means that the position of a pious wife is better than a thousand pious men. If a woman serves her husband well for seven days, the door of the seventh hell will be closed and the door of the eighth paradise will be opened for her.

\section{Kitāb Akhlāq li al-Banīn wa al-Banāt}

This book, written by 'Umar ibn Ahmad Barja', consists of two volumes discussing the ideal morals of boys and girls. It is intended to teach youth how to behave in relation to their parents, teachers and friends. Some advice in the beginning of the book states the importance of al-akhlaq alh\}asanah (good morals) which can bring the happiness in the world and the hereafter. In contrast, al-akhlāq al-sayyi äh (bad morals) can destroy them and make them suffer misfortune. The book also mentions moral obligations of youth.

One of the main topics in the book is Khadijah, the Prophet's wife. She always obeyed Allah and avoided the prohibitions of Allah. As the Prophet wife, Khadijah gave her life to the support of the Prophet's mission. She was patient when finding obstacles in the Prophet's dakwah and accompanied him for twenty four years. Another role model mentioned in this book is a brave female warriornamed Fatimah al-Zahrah whose noble moral character was praised. The quality of Fatimah's moral was the product of the good education given to her from her parents: grew up obeying Allah. Fatimah is described as a warrior who struggled for her family. She always obeyed what her husband ('Ali ibn 'Abi Talib) asked her to do. She educated her children sincerely and respected her husband. Her service for her family was also shown by her cooking for all the members of the family until one day her hands weree blistered. She visited the Prophet and he hugged her gently. 
Another woman who is an important example for many female Muslims is 'Aisyah. She is very diligent in praying and fasting and cries in fear of persecution by Allah. She is also very humble and is not concerned with material prosperity. She gifts her wealth to the poor, and fasts diligently. The personality of 'Aisyah offered as the good example for all women. 'Aisyah was pious, narrated many hadiths, many companions asked her about the Prophet, and she answered their questions amazingly. Those three women are described by 'Umar Ahmad Barja' as role models of pious Muslim.

For boys (akhlāq li al-banin), the morals codes and expectations are very different to those for girls (akhlāq li al-banāt). The material is more simple and related to morals of parents, teachers and friends. The explanation uses examples in the stories about a man, with gentle words, who does not use forbidden words but just uses the suggested words as suggested in the i'tibār (lessons) from the the akhläq li al-banin book. For example, there is a story about a two men named Mahmud and Hamid who obey their teachers, parents and love their friends. Through examples it describes disobedient teenagers whose fate is illustrated in a road accident. After asking for forgiveness from their parents' they return to the right path and Allah blesses them.

The book for men is thicker and more practical than the book for women, because it is males that dominate the marital relationship while females are required to oblige male wishes, as outlined above.

\section{Kitab Adab al-Mu'āsharah}

The Adab al-Mu'äsharah baina al-Zawjain li Takhsil al-Sadāt al-Zawjiyyāt al-Haqiqiyyah (the ways of husband-wife relationship that lead to real happiness), is different from most other books related to the relationships within the family taught in the Islamic Boarding School. This book is 
written by K.H. Akhmad bin Asmuni, the head of Pesantren Hidayat alTullab, Pathok Cement, in Kediri, East Java. In the preface, this book aims to grant equal portion to the positions of husbands and wives in the family suggesting that this will lead to a harmonious family.

This book explains that the strength of the marital relationship is mandated by Allah. Marriage is a very heavy covenant and big responsibility for married couples, therefore, both parties should share mutual understanding. It is importance that husband and wife nurture each others' feelings so that they do not hurt or burden each another. Husband and wife should continuously communicate well and not ignore or isolate one another. Similarly, the husband as head of the family should maintain a balanced approach and be a source of strength and support to his wife.

The book suggests that the husband should allow his wife to do things. The husband should neither restrain nor excessively permit his wife, so that she should not spend money excessively. It is obligatory for a husband to teach his wife about menstruation and prayers because he must educate the family on the Islamic sciences and the basic sciences of the family. Quoting the advice of Iraqi scholars, the author Shalahuddin Muhammad Bahauddin, encourages man to remain attentive to his wife, because his wife's needs are his responsibility. However, he should not advise his wife too often and is encouraged to listen carefully to what his wife says.

This book also suggests that the couple should acknowledge each other's roles and not to undermine each other or make each other feel uneasy. It is also recomended that the husband should not be stingy in providing a livehood to his wife. Another thing recommended is that the husband should communicate well and invite his wife to talk about anything she or the husband does not like, what makes them angry etc. It is suggested that the husband should not scold his wife because of something she did 
not know. Wives should also be given time to rest, because she is neither a servant nor a prisoner (sariyyah).

Women are depicted as gentle and soft - as a crooked rib. Therefore, her husband should know that even if women are like crooked rib, it is not a disgrace but it is an advantage to have a gentle, affectionate, friendly and forgiving nature. Similarly, a husband must not mention the weaknesses of his wife or scold her in front of people, especially their children, because psychologically it can have a negative impact on her mental health.

The second major section in the book of Adab al-Mu'asharah is about the duties of wives. There are some obligations of wives toward husbands. The first obligation is obedience to her husband. The obedience to the husband for the wife is equal to praying five times and fasting during Ramadhan. Indeed, it is very surprising that the obedience to a human (wife towards husband) is deemed equal to obedience to Allah!

\section{Kitab Mukhtașār Ihya' 'Ulüm al-Dīn}

This book is the monumental work of Imam al-Ghazali. It consists of five volumes that discuss many topics related to human life and how humans can become closer to Allah.

The first chapter of this book begins by arguing that there are two differing opinions among scholars concerning marriage. The first opinion supports the excellence of marriage (fadilah), while the second opinion rejects it. Each opinion was supported by normative arguments based on the Quran and the hadith. The verses that encourage marriage are alNūr: 32 and al-Furqān 74. While the rejectionist approach was based on the words of the Prophet which suggest that the "best man after two hundred years of the life of the Prophet is the one who does not bear the burden of life with no family and no children".

In the perspective of Imam al-Ghazali, when Allah wishes to have preferred servants, God will not make the servants busy with matters of 
family (wife and children) and wealth. Another point which is raised by al-Ghazali is when he observeded his friend and concluded that 'those who have a family do not reach the peak of achievement'. ${ }^{31}$

Getting married also leads a man to be with his wife most of the time. al-Ghazali, however, views marriage in a very neutral way, showing opposing opinions, supporting the hadith that encourages a muslim to live in celibacy, as well as the one which advocates marriage. Therefore, according to al-Ghazali, a married couple should hold a walimah (wedding party) by inviting people to witness the marriage ceremony. Therefore, marriage must be known by many people to avoid suspicion. By quoting some hadiths, the importance of holding a walimah is emphasized. Another important topic stated by al-Ghazali in this chapter is about the terms 'aqad and 'aqad, namely, the consent of the guardians and the bride's willingness, either virgin or widowed. Two witnesses, i.e., ijab and qabul, should also be present.

Another point discussed by al-Ghazali is that prospective couples should be initiated through ta'aruf (getting to know each other) in order to create a more happy and loving partnership. Accordingly, their two families should also get to know each other. In al-Ghazali's view, the goals of marriage should be that the married couple have to be devoted to his and her partner and have many children. It is not recomended that a man or woman seek to find a slave or servant in their husband or wife but to find a person who is equal to him or her (kufu'). This will make it easier for them to adjustment to life together.

Other chapters in al-Ghazali's Ihya' 'Ulum al-Din are about the obligations of husbands and wives. A husband is obliged to take good care of his wife, to protect her, support her (nafaqah), teach her (ta' Tim), and be

${ }^{31}$ Abu Hamid al-Ghazali, Ihya’ 'Ulüm al-Dīn, Maktabah Miṣr , Tab'ah Munāqahah wa Murāja'ah, 1998, 32-36. 
polite ( $t a^{\prime} d i b$ ) to her. Meanwhile, a wife is obliged to obey her husband in all things and to care for the property of her husband and family.

\section{Kitab Maw'izātal-Mu'minīn}

This book is about morals, written by Syaikh Muhammad Jamāluddin alQásimy ad-Dimasyqy. Previously, it was not intended for publication, but due to many requests for publication, the book was published under the name Maw'izăt al-Mu'minin, guidance for Muslims.

On the issue of relationships between men and women in marriage, this book actually is not very different to al-Ghazali's Ihȳa' 'Ulüm al-Din. It differs only in detail and examples. In the chapter on marriage, the book begins by reminding about Allah's and the Prophet commands, and suggests that if a muslim wants to get married, the purpose is for making many offsprings and strenthening brotherhood. In adiition, marriage can broaden descent and kinship, keep men's and women's eyes and genitals from forbidden objects and activities. The benefits of marriage are procreation, release of libido and lust in a proper way so that men and women can create the spirit of the family and prioritise and value the family.

Maw'izăt al-Mu'minin explains that women become the object of marriage. They are sought by men. A good prospective wife has several requirements such as they should be pious muslimah, have good behavior, be good looking, be able to produce offsprings and not be a close relative. The religion is the first requirement that should be the main consideration in marriage because the persistence of religion will strengthen and give powers in building marriage. The other requirement is that women have a gentle manner. Politeness is said to bring goodness to all aspects. The author states that impolite woman will have more negative impacts than good ones. Beauty is another consideration because the beauty can motivate the household. But beauty cannot become the main reason 
because it can reduce other interests and levels of sincerity. Beauty is expected increase the desire to make the family relationship harmonious. The next requirement that must be considered is easy mahar. A woman who commands a very expensive mahar will be difficult for the groom to approach. Every man is obsessed, in the point of view of Muhammad Jamaluddin al-Qasimy, to get a woman who can marry soon, love her husband fast, have children fast and who requests a cheap mahar.

Similarly, women are expected to be fertile and able to reproduce children fast. It is suggested that men should find a woman who is still a virgin, according to the author, because virginity can make both man and woman have more desire. The other factor that should be considered in seeking the candidate of wife is to make sure that she is from good family, practices her religion, has a good level of education and is not a close relative (mahräm). ${ }^{32}$

\section{Conclusion}

Based on the explanations of the above texts, it can be concluded that the misogynist epistemology sistematically places women as the second class. The epistemology of knowledge is designed to control them. The knowledge taught in the Islamic Boarding Schools and socialized in daily life of pesantren incorporates misogynist gender-biased hadiths, which then permea feminist epistemology into the knowledge frame of pesantren. This is because feminist epistemology enables an understanding of the problems faced by women. The interpretation of the texts should be done from the perspective of feminists to incorporate the needs of females in contemporary context. To do this, female scholars who have a comprehensive understanding of Islam and the texts are needed. In addition, the socialization of misogynist hadiths in Islamic boarding

\footnotetext{
${ }^{32}$ Maw'iz̧ăt al-Mu'minin, Vol. I, Huqūq al-Ṭaba' Maḥfuẓah, 111-130.
} 
schools leads to a situation in which the charismatic power of Kyai and Nyai influences the decision making. The primary method of socializing Islamic values in Islamic boarding schools is to maintain the traditions and norms of religious teachings taken from misogynist hadiths. Further, the teachings are delivered through weekly Islamic discussions led by Kyai or Nyai. Another method of socialisation is through reinforcement of similar misogynist messages through textbooks used to teach students every day.

Finally, we need to realize that it is necessary to use new strategies in understanding misogynist hadiths. It is important to employ an interdisciplinary approach, incorporating history, sociology, and anthropology, without positioning the Islamic boarding schools as the critisized object. This requires a model of understanding that can accomodate the principles of maqāsid al-shari a in Islam in Islamic boarding schools.

It is suggested that learning methods should be dialogical by engaging staff, teachers, students and the wider society. This model will create a more open and dialogical cultures. The educational system of Islamic boarding schools can then hopefully produce students who are more articulate and expressive in giving their opinions and points of view, especially on crucial topics like misogynist hadiths in Indonesia. Finally, this will create an atmosphere of new openness and understanding that men and women are truly equal.

\section{Bibliography}

al-Bagdadi, al-Khatib. al-Kifayah fi 'Ilm al-Riwāyah. Beirut: al-Venerated al'Ilmiyah, $1358 \mathrm{H}$

al-Damami, Musfir 'Azmillah. Maqāyis Naqd Mutūn al-Sunnah. Riyaḍ: Saudiyyah, 1984.

al-Jawābi, Muhammad Tahir. Juhūd al-Muhaddithin Naqd fi al-Matn al-Hadith alSharif al-Nabawy. Tunis: n.p, n.a.

al-Khatib, Muhammad 'Ajjaj. Ușūl al-Hadisth wa Muṣtalahưh. Beirut: Dār al- 
Fikr, 1989.

Amal, Taufiq Adnan. Islam dan Tantangan Modernitas. Bandung: Mizan, 1990. An-Na'im, Abdullah Ahmed. Dekontruksi Syariah. Trans. Umar. Yogyakarta: LKiS. 1994.

Auda, Jasser. Al-Maqasid untuk Pemula. Trans. Ali Abdel mon'im. Yogyakarta: Diva Press, 1997.

Brittan, Arthur and Mary Maynard. Sexism. Racism. and Oppression. New York: Basil Blackwell, 1984.

Dhofier, Zamakhsyari. Tradisi Pesantren. Jakarta: LP3ES, 1982.

El Fadl, Khaled Abou, "Faith-Based Determination Assumptions and demeaning to Women," in R. Hidayat. S. Schlossberg and AH Rambadeta (eds). Islam, Women and the New World Order. Yogyakarta: Center for Women's Studies UIN Sunan Kalijaga, 2006.

Engineer, Asghar Ali. The Rights of Women in Islam. New York: St.Martin's Press, 1996.

Fazlurrahman. Membuka Pintu Ijtihad. Trans. Anas Mahyudin. New York: Library, 1984.

Hirst, J.S. and Thomas L., "Introduction: Playing for Real: Hindu Role Models. Religion and Gender," in Hirst. J.S. and Thomas L. (ed.). Playing for Real: Hindu Role Models. Religion and Gender. Oxford: Oxford University Press.

Mas'udi, Masdar Farid. Islam dan Hak-Hak Reproduksi Perempuan. Bandung: Mizan, 1997.

Musthofa, M. Manhaj al-Naqd 'inda al-Muhaddithin. Riyad: al-'Umairoh, 1982. Rosenthal, D. A. and Feldman. S. S., "The acculturation of Chinese immigrants: effects on family functioning of length of residence in two cultural contexts," Journal of Genetic Psychology. Vol. 4. (1990).

Salih, Subhi. 'Ulūm al-Hadith wa Mustalahuh. Beirut: Dār al-'Ilm li al-Malayin, 1988.

Talbani, Aziz dan Parven Hasanali. "Adolescent females between tradition and modernity: gender role socialization in South Asian immigrant culture." Journal of Adolescence. Vol. 23. (2000)

Turmudi, Endang. Perselingkuhan Kyai dan Kekuasaan. Yogyakarta: LKIS. 2004

Umar, Nazaruddin. Argumen Kesetaraan Gender Perspektif Al-Qur'an. Jakarta: Paramadina, 1999.

Wahid, Abdurrahman. "Introduction to the book." Kitab Kuning. Pesantren dan Tarikat. Bandung: Mizan. 1995.

Yuslim, Nawir. Ulumul Hadith. New York: Pearl Source, n.a. 